\title{
CHD2 haploinsufficiency is associated with developmental delay, intellectual disability, epilepsy and neurobehavioural problems
}

\author{
Sébastien Chénier ${ }^{1}$, Grace Yoon ${ }^{2}$, Bob Argiropoulos ${ }^{3}$, Julie Lauzon ${ }^{3}$, Rachel Laframboise ${ }^{4}$, Joo Wook Ahn', \\ Caroline Mackie Ogilvie ${ }^{5}$, Anath C Lionel ${ }^{6}$, Christian R Marshall ${ }^{6}$, Andrea K Vaags ${ }^{7}$, Bita Hashemi ${ }^{2}$, Karine Boisvert ${ }^{4}$, \\ Géraldine Mathonnet ${ }^{8}$, Frédérique Tihy ${ }^{8}$, Joyce So ${ }^{9}$, Stephen W Scherer ${ }^{6}$, Emmanuelle Lemyre ${ }^{8}$ \\ and Dimitri J Stavropoulos ${ }^{10^{*}}$
}

\begin{abstract}
Background: The chromodomain helicase DNA binding domain (CHD) proteins modulate gene expression via their ability to remodel chromatin structure and influence histone acetylation. Recent studies have shown that CHD2 protein plays a critical role in embryonic development, tumor suppression and survival. Like other genes encoding members of the CHD family, pathogenic mutations in the CHD2 gene are expected to be implicated in human disease. In fact, there is emerging evidence suggesting that CHD2 might contribute to a broad spectrum of neurodevelopmental disorders. Despite growing evidence, a description of the full phenotypic spectrum of this condition is lacking.

Methods: We conducted a multicentre study to identify and characterise the clinical features associated with haploinsufficiency of CHD2. Patients with deletions of this gene were identified from among broadly ascertained clinical cohorts undergoing genomic microarray analysis for developmental delay, congenital anomalies and/or autism spectrum disorder.
\end{abstract}

Results: Detailed clinical assessments by clinical geneticists showed recurrent clinical symptoms, including developmental delay, intellectual disability, epilepsy, behavioural problems and autism-like features without characteristic facial gestalt or brain malformations observed on magnetic resonance imaging scans. Parental analysis showed that the deletions affecting CHD2 were de novo in all four patients, and analysis of high-resolution microarray data derived from 26,826 unaffected controls showed no deletions of this gene.

Conclusions: The results of this study, in addition to our review of the literature, support a causative role of CHD2 haploinsufficiency in developmental delay, intellectual disability, epilepsy and behavioural problems, with phenotypic variability between individuals.

Keywords: Autism spectrum disorder, CHD2, Developmental delay, Epilepsy, Learning disability

\section{Background}

Chromatin remodeling is the dynamic modification of chromatin architecture essential to many biological processes, including cell division, gene expression, and DNA replication, packaging and repair [1-3]. The chromodomain helicase DNA binding (CHD) proteins belong to the

\footnotetext{
* Correspondence: james.stavropoulos@sickkids.ca

${ }^{10}$ Department of Paediatric Laboratory Medicine, The Hospital for Sick Children and University of Toronto, 555 University Avenue, Toronto, ON M5G 1X8, Canada

Full list of author information is available at the end of the article
}

SNF2-related superfamily of ATPases, which use the energy from ATP hydrolysis to change nucleosome positioning, composition and chromatin structure. The CHD family is defined by the presence of tandem chromo (chromatin organisation modifier) domains in the N-terminal region and a central SNF2-related helicase/ATPase domain [4]. The latter is the catalytic core mediating chromatin alteration. Members of the CHD family are divided into three subfamilies according to their additional structural motifs. (1) CHD1 and CHD2 possess a C-terminal DNA binding domain recognizing AT-rich DNA motifs.

\section{Ciomed Central}

(C) 2014 Chénier et al.; licensee BioMed Central Ltd. This is an Open Access article distributed under the terms of the Creative Commons Attribution License (http://creativecommons.org/licenses/by/2.0), which permits unrestricted use, distribution, and reproduction in any medium, provided the original work is properly credited. The Creative Commons Public Domain Dedication waiver (http://creativecommons.org/publicdomain/zero/1.0/) applies to the data made available in this article unless otherwise stated. 
(2) CHD3 and CHD4 contain a pair of plant homeodomain zinc finger domains in their $\mathrm{N}$-terminal regions and lack a DNA binding domain. (3) CHD5 to CHD9, which contain diverse additional functional domains such as the BRK (Brahma and Kismet) domain, SANT-like (switching-defective protein 3 , adaptor 2 , nuclear receptor corepressor, transcription factor IIIB) domain, CR domain and DNA binding domain $[1,5]$.

As CHD proteins play pivotal roles in modulating chromatin structure and are involved in processes such as gene activation and repression, DNA recombination and repair, cell-cycle regulation, development and cell differentiation, dysregulation of these proteins may have adverse effects on human development. Heterozygous mutations of the CHD7 gene are known to cause the multisystem abnormalities associated with autosomal dominant CHARGE syndrome (coloboma, heart anomaly, choanal atresia, retardation, genital and ear anomalies) [OMIM:214800]. Characteristic anomalies include ocular coloboma, choanal atresia, cranial nerve defects, distinctive external and inner ear abnormalities, hearing loss, cardiovascular malformations, intellectual disability (ID), urogenital anomalies and growth retardation. More recently, exome sequencing studies have shown loss of function mutations affecting one allele of $\mathrm{CHD} 8$ to be associated with autism spectrum disorder (ASD) [6-8].

There is emerging evidence showing CHD2 haploinsufficiency is associated with neurodevelopmental abnormalities. Deletions affecting this gene are very rare, and, so far, there is only one case report of a child with global developmental delay, epilepsy and ASD who was found to have a de novo deletion encompassing the RGMA and $C H D 2$ genes [9]. However, because of the importance of $R G M A$ in central nervous system axonal growth, haploinsufficiency of this gene was thought to be a good candidate to explain the patient's developmental delay and seizures. A deletion affecting CHD2 was also reported in the supplemental data derived from genomic microarray analysis of 996 patients ascertained to have ASD [10]. This deletion involves CHD2, but not RGMA, and the patient was reported to have ASD and mild ID with no history of seizures or language delay. Recent studies have implicated de novo intragenic sequence mutations in CHD2 in individuals with ID and a range of epileptic encephalopathies [11-13]. Although there is increasing evidence suggesting that mutations in CHD2 contribute to a broad spectrum of neurodevelopmental disorders, a description of the full phenotypic spectrum is lacking.

In order to investigate the role of CHD2 haploinsufficiency in neurodevelopmental disorders, we describe the first series of patients with deletions affecting CHD2 from among a cohort of 42,313 patients broadly ascertained by clinical genetics laboratories to have developmental delay, intellectual disability, multiple congenital anomalies and/ or ASD. We also present a review of the literature to correlate our patients' phenotypes with those previously reported with deletions and loss-of-function sequence mutations affecting this gene.

\section{Methods}

We conducted a multicentre study of retrospective genomic copy number variation (CNV) data from six genetic diagnostics laboratories (see Additional file 1: Table S1), to collect phenotypic information from patients with deletions affecting CHD2. For all patients, phenotypic information was collected from genetics clinic assessments and medical chart reviews. This study is compliant with the research ethics boards of each participating institution. Signed informed consent was obtained from all study participants or their legal representatives. DNA extracted from uncultured cells, typically from peripheral blood lymphocytes, was used to perform genomic CNV analysis in all participating laboratories. Microarray experiments were performed according to the manufacturer's instructions. As described in Table S1, the microarray platforms used at each of the six diagnostic centres were oligonucleotide array-based. Deletions were confirmed, and parental follow-up studies were performed with multiplex ligation-dependent probe amplification (MLPA), array comparative genomics hybridization (aCGH) or fluorescence in situ hybridization (FISH) analysis. FISH analysis was performed using fosmid G248P83477D10 or CTD2314 N10 bacterial artificial chromosome. We investigated the frequency of deletions affecting CHD2 in highresolution CNV data from among 13 control cohorts comprising a total of 26,826 individuals [10,14-26].

\section{Results}

We reviewed genomic CNV data from six genetic diagnostics laboratories that perform microarray analysis for patients broadly ascertained to have delayed developmental milestones in motor, speech and/or cognition skills (developmental delay); diagnosis of global developmental delay or ID, multiple congenital anomalies; and/ or ASD. We identified four deletions affecting CHD2 exonic sequences from a total of 42,313 patients analyzed. The deletions ranged in size from approximately $78 \mathrm{~kb}$ to $237 \mathrm{~kb}$, with only one case also involving the RGMA gene, and all were found to be de novo (Figure 1). No other clinically significant CNVs were found in these patients. The clinical findings in these patients included developmental delay, learning difficulties or ID in all four patients, as well as seizures in three patients (Table 1). The dysmorphic features observed in each of these patients are described in turn in the subsections below. However, no characteristic facial gestalt was found. Brain magnetic resonance imaging (MRI) did not 


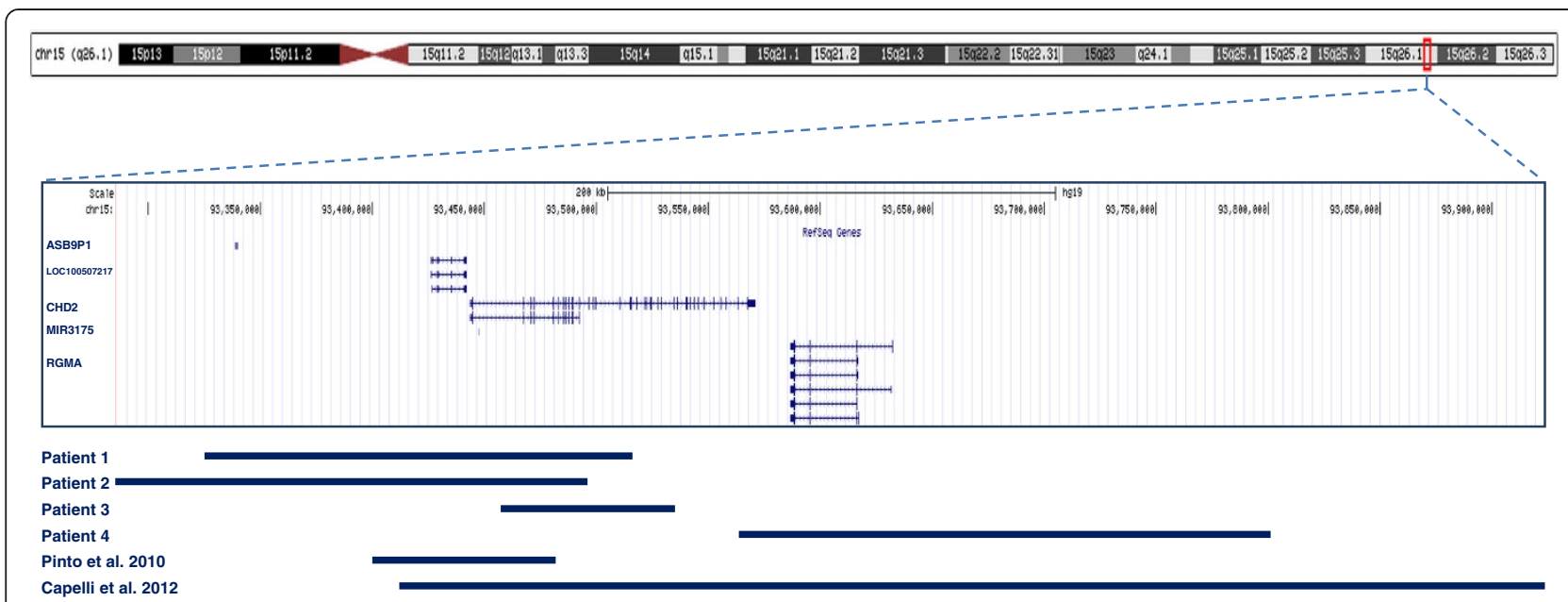

Figure 1 Summary of deletions observed in our patients and reported in the literature.

reveal any malformations in our patients. Analysis of data derived from 26,826 individuals from populationbased control cohorts evaluated by high-resolution $\mathrm{CNV}$ analysis did not show deletions affecting exonic sequences of $C H D 2$, confirming the extreme rarity of this deletion in the general population (see Additional file 1: Table S2).

\section{Patient 1}

Patient 1 has a 191-kb de novo deletion involving CHD2, the $A S B 9 P 1$ noncoding pseudogene, the uncharacterised LOC100507217 noncoding gene and microRNA MIR3175 (Figure 1). This 11-year-old girl was referred for medical genetics evaluation because she had fine and gross motor delays as well as seizures. She was born by Caesarean section at 38 weeks gestation with a birth weight of 2,977 g (25th percentile) to healthy nonconsanguineous Caucasian parents. She sat upright at age 1 year, walked at 22 months and spoke her first words at 3 years. She had learning disabilities with specific deficits in language and mathematics, and she repeated grade 3. She also had short-term memory problems, a short attention span, poor social skills and aggressive behaviour. She developed seizures at 6 years of age, which were characterised by absence seizures with eyelid myoclonia (Jeavons syndrome) and confirmed by video electroencephalogram (EEG). Her medications included lamotrigine and ethosuximide. She also had auditory neuropathy consistent with bilateral mild loss of peripheral auditory function at higher frequencies. Her physical examination revealed that she had subtle dysmorphic features, with a square-shaped face, high forehead, short philtrum, thin upper vermillion border of the lip and prominent columella. She had mild thoracic scoliosis, fusion of the proximal interphalangeal joint in both thumbs, bilateral fifth-finger brachydactyly, tapered fingers and cutaneous 2-3 syndactyly of the toes.
Her neurological examination was normal, with the exception of frequent episodes of eyelid fluttering bilaterally. An MRI scan taken when she was 9 years of age was normal, as was a skeletal survey; however, an abdominal ultrasound showed a duplex right kidney. She had a normal acylcarnitine profile and normal plasma amino acids, electrolytes, lactate, urinary organic acids and FRAXA and FRAXE fragile X syndrome tests.

\section{Patient 2}

Patient 2 is a 9 -year-old girl who has a 210 -kb deletion affecting $C H D 2$, the $A S B 9 P 1$ noncoding pseudogene, the uncharacterised LOC100507217 noncoding gene and microRNA MIR3175 (Figure 1), similar to patient 1. She was referred to medical genetics for mild delays in motor and language development as well as seizures. She was born at term (41 weeks gestation) after an uneventful pregnancy to nonconsanguineous parents. Her birth weight was $3,610 \mathrm{~g}$ (50th percentile). She was found to have mild axial hypotonia as an infant. She first walked at age 15 months. She had feeding problems in infancy. She was diagnosed with attention-deficit/hyperactivity disorder and was being treated with dextroamphetamine and amphetamine. She showed limited social skills without any other features associated with ASD. She had visual perceptual disabilities, a communication disorder characterised by mixed receptive and expressive language difficulties and short-term memory problems. She repeated grade 1 , and her performance on the Wechsler Intelligence Scale for Children-Fourth Edition was classified in the Low Average range for her age group. Absence seizures that began at 3 years of age were being treated with levetiracetam and valproic acid. Her physical examination showed that she had reduced body fat mass, a prominent forehead, a triangular face, full lips, widely spaced maxillary central incisors and 
Table 1 Clinical characteristics of patients with CHD2 deletions ${ }^{\mathrm{a}}$

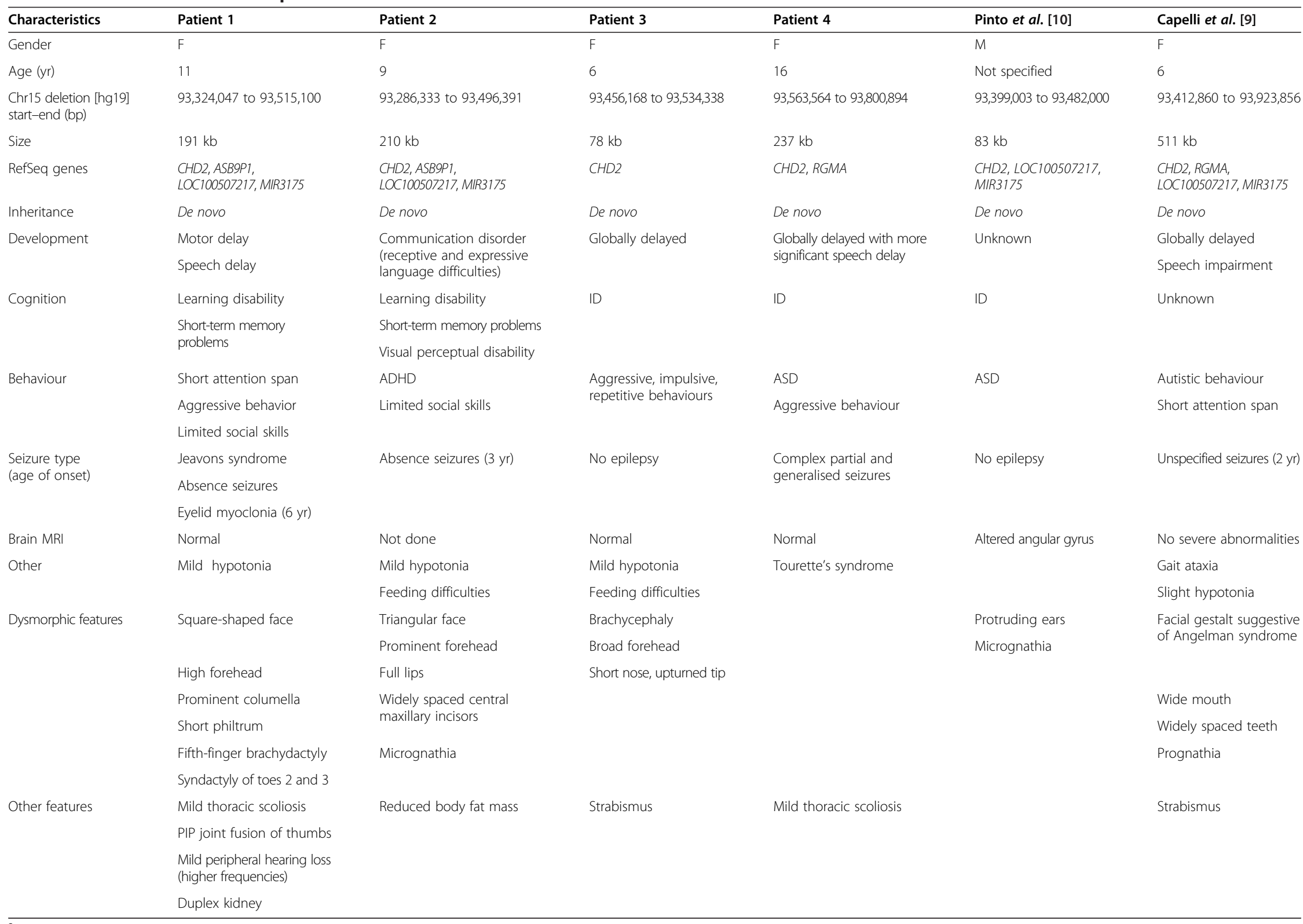


micrognathia. Her neurological examination was normal. Investigations performed for the assessment of her seizures and developmental delays included G-banding karyotype, a metabolic screen including carnitine level and acylcarnitine profile, plasma amino acids, and urinary organic acids, all of which were normal. An EEG showed generalised epileptogenic dysfunction and photosensitivity. No brain imaging was performed.

\section{Patient 3}

Patient 3 has a de novo 78-kb intragenic deletion affecting several 5' exons of CHD2. No other gene was deleted in this patient. This 6-year-old girl was referred to the clinical genetics clinic for assessment of her profound delay in motor development and hypotonia. Her mother's pregnancy was unremarkable, and she was born by Caesarean section at term with a birth weight of $2,920 \mathrm{~g}$ (25th percentile) to healthy nonconsanguineous parents. She had feeding difficulties as an infant and had ongoing issues with chewing and swallowing food properly in early childhood. She was found to have mild hypotonia in infancy, but she had normal tone at age 6 years. She sat upright at 9 months of age and walked at 26 months. At 6 years of age, she was not able to climb stairs with alternating feet and had difficulty pedaling a tricycle. She had mild delays in her fine motor skills, and, although she had normal speech, her language comprehension skills were delayed. She scored below the first percentile on the Wechsler Preschool and Primary Scale of Intelligence-Third Edition full-scale IQ test at 4 years of age. She displayed repetitive behaviours, such as walking in circles, mouthing objects and headbanging, but she did not meet the criteria for ASD. She had a history of aggressive behaviour towards others, which has mostly resolved. She was described as having lack of insight and judgment, as well as impulsive behaviour. She had never had seizures, and her EEG and brain MRI were normal. Her medical history is significant for strabismus. Her physical examination revealed that she had normal growth parameters, including a normal head circumference. Her facial features included brachycephaly, a broad forehead with a short nose, and an upturned nasal tip. Her physical examination was otherwise unremarkable. Molecular genetic testing showed normal results for methylation-specific MLPA analysis for PraderWilli and Angelman syndromes, MECP2 sequencing and FRAXA fragile X syndrome testing.

\section{Patient 4}

Patient 4 was found to have a $237-\mathrm{kb}$ de novo deletion involving CHD2 and RGMA. Analysis by aCGH in this 16-year-old girl was performed because of poorly controlled epilepsy as well as ASD. She is known to have very challenging behavioural issues and Tourette's syndrome.
She presented in childhood with delays in motor, speech and cognition, with a more significant delay in language. At school, she exhibited difficulties in spelling and reading skills and had difficulty with mathematics. Her IQ ranged between 35 and 49. Complex partial and generalised seizures were noted between 3 and 24 months of age. Her physical examination showed that she had normal growth parameters with mild thoracic scoliosis. No striking dysmorphic features were reported. Her brain MRI was normal.

\section{Discussion}

We present the clinical features of four individuals with heterozygous de novo deletions affecting $\mathrm{CHD} 2$ who were identified from among a phenotypically heterogeneous cohort of 42,313 patients with developmental delays or ID, multiple congenital anomalies and/or ASD. The clinical symptoms of our patients are consistent with and include delays in speech and/or motor development, seizures, ID and/or learning difficulties, and neurobehavioural abnormalities, which may include autistic features, ADHD and/or aggressive behaviour. Our examination of 26,826 individuals from 13 control cohorts did not show any deletion affecting exonic sequences of this gene, indicating that deletions affecting CHD2 are extremely rare.

Our review of the literature on CHD2 deletions turned up one case report describing a de novo deletion affecting CHD2 and RGMA in a patient with speech and motor delays, including ID, gait ataxia, dysmorphic features, autistic features with attention deficit, and seizures beginning at 24 months of age [9]. These features were attributed to haploinsufficiency of RGMA and/or CHD2. In our cohort, only one patient had a heterozygous deletion affecting CHD2 and RGMA. Nevertheless, all of our patients had similar clinical findings, suggesting that CHD2 contributes significantly to the broad spectrum of neurodevelopmental disorders and mild dysmorphic features seen in patients with CHD2 deletions (Table 1). In addition, in an examination of the supplemental data from genomic CNV analysis of an ASD cohort, Pinto et al. [10] reported a de novo deletion of CHD2 in one patient with mild ID and ASD but no seizures [10]. This suggests that epilepsy may not always be present in patients with $\mathrm{CDH} 2$ haploinsufficiency, as we observed in one of our four patients. In another report in the literature, Kulkarni et al. [27] described a de novo translocation $\mathrm{t}(\mathrm{X} ; 15)(\mathrm{p} 22.2 ; \mathrm{q} 26.1) \mathrm{dn}$ disrupting CHD2 in a child with developmental delay, scoliosis and hirsutism. It is possible, however, that the clinical presentation of their patient may have been affected by disrupted expression of other genes near the translocation breakpoints. Interestingly, two of our patients with $C H D 2$ deletions had mild thoracic scoliosis, suggesting that $C H D 2$ disruption 
Table 2 Clinical characteristics of patients with CHD2 single-point DNA mutation ${ }^{\text {a }}$

\begin{tabular}{|c|c|c|c|c|c|c|c|c|c|c|c|}
\hline \multirow{2}{*}{$\begin{array}{l}\text { Characteristics } \\
\text { Gender }\end{array}$} & \multirow{2}{*}{$\frac{\text { Rauch et al. [12] }}{F}$} & \multicolumn{6}{|c|}{ Carvill et al. [11] } & \multirow{2}{*}{$\begin{array}{c}\text { Allen et al. [13] } \\
M\end{array}$} & \multicolumn{3}{|c|}{ Suls et al. [28] } \\
\hline & & M & $\mathrm{F}$ & $\mathrm{F}$ & $M$ & $M$ & M & & $M$ & $\mathrm{~F}$ & $M$ \\
\hline Age $(y r)$ & 5.75 & 17 & 12 & 29 & 12 & 15 & 2.5 & Unknown & 6 & 24 & 6 \\
\hline $\begin{array}{l}\text { Protein change } \\
\text { (type) }\end{array}$ & $\begin{array}{c}\text { p.Thr604 } \\
\text { Leuf**19 } \\
\text { (frame shift) }\end{array}$ & $\begin{array}{l}\text { p.Glu1412 } \\
\text { Glyfs*64 } \\
\text { (frame shift) }\end{array}$ & $\begin{array}{l}\text { p.Arg121* } \\
\text { (frame shift) }\end{array}$ & $\begin{array}{c}\text { p.Gly491 } \\
\text { Valfs*13 } \\
\text { (frame shift) }\end{array}$ & $\begin{array}{l}\text { p.Arg1644 } \\
\text { Lysfs*22 } \\
\text { (frame shift) }\end{array}$ & $\begin{array}{l}\text { p.Trp548Arg } \\
\text { (missense) }\end{array}$ & $\begin{array}{l}\text { p.Leu823Pro } \\
\text { (missense) }\end{array}$ & $\begin{array}{l}\text { c. } 1502+1 \mathrm{G}>\mathrm{A} \\
\text { (splice donor) }\end{array}$ & $\begin{array}{c}\text { c. } 1810-2 A>C \\
(p . ?)\end{array}$ & $\begin{array}{l}\text { c.4971G>A } \\
(\text { p.Trp1657*) }\end{array}$ & $\begin{array}{l}\text { c. } 1396 C>T \\
\text { (p.Arg466*) }\end{array}$ \\
\hline Inheritance & De novo & De novo & De novo & De novo & De novo & De novo & De novo & De novo & De novo & De novo & De novo \\
\hline Development & $\begin{array}{l}\text { Globally } \\
\text { delayed }\end{array}$ & Mild delay & $\begin{array}{l}\text { Normal prior } \\
\text { to epilepsy }\end{array}$ & $\begin{array}{l}\text { Unspecified } \\
\text { delay }\end{array}$ & $\begin{array}{l}\text { Normal before } \\
\text { seizure onset }\end{array}$ & $\begin{array}{l}\text { Unspecified } \\
\text { delay }\end{array}$ & $\begin{array}{l}\text { Unspecified } \\
\text { delay }\end{array}$ & $\begin{array}{l}\text { Unspecified } \\
\text { delay }\end{array}$ & $\begin{array}{l}\text { Normal prior } \\
\text { to epilepsy }\end{array}$ & $\begin{array}{l}\text { Normal prior } \\
\text { to epilepsy }\end{array}$ & $\begin{array}{c}\text { Subtle motor } \\
\text { and speech } \\
\text { delay }\end{array}$ \\
\hline Cognition & Mild ID & Moderate ID & Severe ID & Severe ID & Severe ID & Moderate ID & Severe ID & Unknown & Moderate ID & Moderate ID & Mild ID \\
\hline \multirow[t]{2}{*}{ Behaviour } & \multirow{2}{*}{$\begin{array}{l}\text { Uncontrolled } \\
\text { behavioural } \\
\text { anomalies }\end{array}$} & \multirow{2}{*}{$\begin{array}{l}\text { ASDBehavioural } \\
\text { problems }\end{array}$} & \multirow[t]{2}{*}{ Unknown } & \multirow[t]{2}{*}{ Unknown } & \multirow[t]{2}{*}{ Unknown } & \multirow[t]{2}{*}{ Unknown } & \multirow[t]{2}{*}{ ASD } & \multirow[t]{2}{*}{ Unknown } & \multirow[t]{2}{*}{ Unknown } & \multirow[t]{2}{*}{ Unknown } & ASD \\
\hline & & & & & & & & & & & ADHD \\
\hline $\begin{array}{l}\text { Seizure type } \\
\text { (age of onset) }\end{array}$ & AS (5 yr) & $\begin{array}{c}\text { AtS }(1 \mathrm{yr}), \text { AS, FS, } \\
\text { MJ, MJ-AS, TC }\end{array}$ & $\begin{array}{c}\text { MJ (1 yr), MA, } \\
\text { NCS, TC, TS }\end{array}$ & $\begin{array}{c}\text { Atypical AS (1 yr), } \\
\text { AtS, LGS, MJ, NCS, } \\
\text { SE, TC, TS }\end{array}$ & $\begin{array}{c}\text { AtS (2 yr), MJ, } \\
\text { SE, TC }\end{array}$ & $\begin{array}{c}\text { TC (3 yr), FDS, } \\
H, M J\end{array}$ & $\begin{array}{c}\text { MJ (2.5 yr), FDS, } \\
\text { MJ, MA, TS }\end{array}$ & $\begin{array}{c}\text { TC (6 mo), } \\
\text { Atypical AS, AtS, } \\
\text { FDS, LGS, MS }\end{array}$ & $\begin{array}{l}\text { FS (14 mo), } \\
\text { Atypical AS, } \\
\text { MS, SE, TC }\end{array}$ & $\begin{array}{l}\text { FS }(2 \mathrm{yr}) \\
\text { MA, MS, TC }\end{array}$ & $\begin{array}{c}\text { TC }(3.5 \mathrm{yr}) \\
\text { Atypical AS, } \\
\text { AtS, FS, H, MS }\end{array}$ \\
\hline Brain MRI & Unknown & Unknown & Unknown & Unknown & Unknown & Unknown & Unknown & Normal & Normal & Normal & $\begin{array}{l}\text { Nonspecific } \\
\text { atrophy }\end{array}$ \\
\hline \multirow[t]{2}{*}{ Other } & & & & & & & & \multirow{2}{*}{$\begin{array}{c}\text { Right } \\
\text { hemibody } \\
\text { weakness }\end{array}$} & Dysarthria & & \multirow[t]{3}{*}{ Mild ataxia } \\
\hline & & & & & & & & & Ataxia & & \\
\hline Other features & $\begin{array}{l}\text { Duane } \\
\text { anomaly }\end{array}$ & & & & & & & $\begin{array}{l}\text { Language } \\
\text { regression } \\
\text { after corpus } \\
\text { callosotomy }\end{array}$ & & & \\
\hline
\end{tabular}


may predispose individuals to vertebral anomaly, as reported by Kulkarni et al. [27] and as described in the Chd2-mutant mouse model [5,27]. Together, the consistent clinical features among patients diagnosed by routine clinical microarray and the de novo occurrence of all deletions affecting CHD2 reported thus far support a causative role of $\mathrm{CHD} 2$ haploinsufficiency for developmental delay, intellectual disability, epilepsy and behavioural problems, with phenotypic variability among individuals (Table 1).

The results of recent studies in which researchers used massively parallel sequencing in patient cohorts investigated for epilepsy, ASD or ID provide supporting evidence for a role of CHD2 haploinsufficiency in manifestation of the characteristics observed in our patients (Table 2). Carvill et al. [11] performed sequence analysis of 66 candidate genes in 500 patients clinically diagnosed with epileptic encephalopathy. They found mutations predicted to be pathogenic in four patients with heterozygous de novo nonsense mutations and in two patients with de novo missense mutations disrupting the highly conserved residues in the SNF2-related helicase/ ATPase domain. They described all six of their patients as having moderate to severe ID in addition to the onset of myoclonic seizures by 3 years of age. A role for CHD2 in ID is further substantiated by a report of a de novo frameshift mutation identified by exome sequencing in one patient [12]. In another report, an exome sequencing screen carried out for de novo mutations in patients with infantile spasms and Lennox-Gastaut syndrome revealed one patient with a CHD2 missense mutation [13]. More recently, Suls et al. [28] found three patients carrying de novo CHD2 sequence mutations who had febrile seizures followed by therapy-resistant generalised seizures (Table 2). In addition, they showed that a knockdown of chd2 in zebrafish resulted in clinical and electrographic seizures [28]. Interestingly, none of our four patients with a deletion of CHD2 had febrile seizures. These previous studies, together with our present case series, provide strong evidence that haploinsufficiency of $C H D 2$ is associated with neurodevelopmental disabilities. Despite the presence of mild dysmorphic features in most patients described thus far, no specific facial gestalt has yet been reported. In addition, no brain malformation has been visualised by MRI. Although massively parallel sequencing studies suggest a strong association between CHD2 haploinsufficiency and seizures or ID, our study, which is based on broadly ascertained clinical cohorts, shows that such associations are not always observed. Some phenotypic variability between individuals seems to be present. Future studies will reveal whether other genetic factors influence the phenotype of this disorder or if CHD2 haploinsufficiency is associated with other phenotypes.

\section{Conclusions}

Herein we describe the first series of patients with deletions affecting $\mathrm{CHD} 2$. We provide additional evidence that deletions and pathogenic point mutations affecting CHD2 are associated with neurodevelopmental problems, which include delays in speech and/or motor development, seizures, ID or learning difficulties, minor dysmorphic features and behaviour problems involving social difficulties and maladaptive behaviours. Although haploinsufficiency of CHD2 is associated with a broad spectrum of neurodevelopmental disorders, we show that variability in the clinical expression of the phenotype can be observed. The overview of all currently reported mutations and their associated phenotypic features provided in this study provides a valuable resource for health-care providers caring for individuals with $C H D 2$ mutations.

\section{Additional file}

Additional file 1: Table S1. Number of patients tested and microarray platform used by genetic diagnostics laboratories. Table S2. Control cohorts examined for exonic deletions at CHD2.

\section{Abbreviations}

aCGH: Array comparative genomics hybridization; ADHD: Attention-deficit/ hyperactivity disorder; ASD: Autism spectrum disorder; CHD: Chromodomain helicase DNA binding domain; CNV: Copy number variation; EEG: Electroencephalogram; FISH: Fluorescence in situ hybridization; ID: Intellectual disability; MLPA: Multiplex ligation-dependent probe amplification.

\section{Competing interests}

The authors declare that they have no competing interests.

\section{Authors' contributions}

SC, EL and DJS conceived of this study and participated in its design. SC, GY, $B A, J L, A C L, C R M, J W A, A K V$, SWS, CMO and DJS performed data accumulation and interpretation and participated in manuscript preparation. RL, AKV, KB, GM, FT and JS participated in data accumulation. SC, DJS, GY, $A C L, C R M, A K V, B H, J S$ and SWS participated in critically revising the manuscript. All authors read and approved the final manuscript.

\section{Acknowledgments}

The authors wish to thank the patients and their families for participating in this study. This work was supported by grants from the University of Toronto McLaughlin Centre, Genome Canada through the Ontario Genomics Institute, and the Canadian Institutes of Health Research (CIHR). ACL was supported by a NeuroDevNet doctoral fellowship. SWS holds the GlaxoSmithKline-CIHR Chair in Genome Sciences at the University of Toronto and The Hospital for Sick Children. The authors would like to thank Dr Marsha Speevak for permission to include statistics from the patient database at Credit Valley Hospital. Control data sets were obtained, along with permission for their use, from the database of Genotypes and Phenotypes (dbGaP) (http://www.ncbi.nlm.nih.gov/gap) through dbGaP accession numbers phs000143.v1.p1 (Starr County Health Studies' Genetics of Diabetes Study), phs000091.v2.p1 (GENEVA Genes and Environment Initiatives in Type 2 Diabetes (Nurses' Health Study/Health Professionals Follow-up Study), phs000169.v1.p1 (Whole Genome Association Study of Visceral Adiposity in the Health Aging and Body Composition (Health ABC) Study), phs000303.v1.p1 (Genetic Epidemiology of Refractive Error in the KORA (Kooperative Gesundheitsforschung in der Region Augsburg) Study) and phs000404.v1.p1 (Collaborative Genetic Study of Nicotine Dependence (COGEND); The Genetic Architecture of Smoking and Smoking Cessation). 
The Starr County Health Studies Genetics of Diabetes Study was supported by the National Institute of Diabetes and Digestive and Kidney Diseases (NIDDK) and the NIDDK Central Repositories. Support for the genome-wide association study (GWAS) of the GENEVA Genes and Environment Initiatives in Type 2 Diabetes (Nurses' Health Study/Health Professionals Follow-up Study) was provided by the National Institutes of Health (NIH) Genes, Environment and Health Initiative (GEI) (grant U01 HG004399). The participants in the GWAS derive from The Nurses' Health Study and Health Professionals' Follow-up Study, which are supported by National Institutes of Health grants CA87969, CA55075 and DK58845. Assistance with phenotype harmonization and genotype cleaning, as well as with general study coordination, was provided by the Gene Environment Association Studies GENEVA coordinating center (grant U01 HG004446) and the National Center for Biotechnology Information. Support for genotyping, which was performed at the Broad Institute of the Massachusetts Institute of Technology and Harvard University, was provided by the NIH GEl (grant U01 HG004424). Support for the Johns Hopkins University Center for Inherited Disease Research (CIDR) Visceral Adiposity Study was provided through the Division of Aging Biology and the Division of Geriatrics and Clinical Gerontology, National Institute on Aging, $\mathrm{NIH}$. Assistance with phenotype harmonization and genotype cleaning, as well as with general study coordination, was provided by the Health Aging and Body Composition (Health ABC) Study Investigators. The KORA data set was obtained from the NEI Refractive Error Collaboration (NEIREC) Database, funding support for which was provided by the National Eye Institute, NIH. Funding support for genotyping of the COGEND samples, which was performed at the Center for Inherited Disease Research, was provided by grant 1 X01 HG005274-01. Assistance with genotype cleaning of the COGEND samples, as well as with general study coordination, was provided by the Gene Environment Association Studies (GENEVA) Coordinating Center (grant U01 HG004446). Funding support for collection of COGEND data sets and samples was provided by COGEND (grant P01 CA089392) and the University of Wisconsin Transdisciplinary Tobacco Use Research Center (grants P50 DA019706 and P50 CA084724).

\section{Author details}

${ }^{1}$ Division of Medical Genetics, Department of Pediatrics, Centre Hospitalier Universitaire de Sherbrooke, 3001, 12 E Avenue Nord, Sherbrooke, QC J1H 5N4, Canada. ${ }^{2}$ Division of Clinical and Metabolic Genetics, Department of Pediatrics, The Hospital for Sick Children and University of Toronto, 555 University Ave, Toronto, ON M5G 1X8, Canada. ${ }^{3}$ Department of Medical Genetics, Alberta Children's Hospital Research Institute, University of Calgary, 2888 Shaganappi Trail NW, Calgary, AB T3B 6A8, Canada. ${ }^{4}$ Division of Medical Genetics, Department of Pediatrics, Centre Hospitalier Universitaire de Québec, 2705 Boulevard Laurier, Québec, QC G1V 4G2, Canada. ${ }^{5}$ Cytogenetics Department, Guy's and St Thomas' NHS Foundation Trust, Great Maze Pond, London SE1 9RT, UK. 'Department of Molecular Genetics and McLaughlin Centre, The Centre for Applied Genomics and Program in Genetics and Genome Biology, The Hospital for Sick Children and University of Toronto, 686 Bay Street, Toronto, ON M5G 0A4, Canada. ${ }^{7}$ Division of Anatomic Pathology and Cytopathology, Cytogenetics Laboratory, Calgary Laboratory Service and Alberta Children's Hospital, 2888 Shaganappi Trail NW, Calgary, AB T3B 6A8, Canada. ${ }^{8}$ Division of Medical Genetics, Department of Pediatrics, Centre Hospitalier Universitaire de Sainte-Justine, Université de Montréal, 3175, Chemin de la Côte-Sainte-Catherine, Montréal, QC H3T 1C5, Canada. ${ }^{9}$ Department of Clinical Genetics, Lakeridge Health Oshawa, 1 Hospital Court, Oshawa, ON L1G 2B9, Canada. ${ }^{10}$ Department of Paediatric Laboratory Medicine, The Hospital for Sick Children and University of Toronto, 555 University Avenue, Toronto, ON M5G 1X8, Canada.

Received: 12 December 2013 Accepted: 3 April 2014 Published: 22 April 2014

\section{References}

1. Hall JA, Georgel PT: CHD proteins: a diverse family with strong ties. Biochem Cell Biol 2007, 85:463-476.

2. Tsukiyama T: The in vivo functions of ATP-dependent chromatinremodelling factors. Nat Rev Mol Cell Biol 2002, 3:422-429.

3. Smith CL, Peterson CL: ATP-dependent chromatin remodeling. Curr Top Dev Biol 2005, 65:115-148.

4. Tajul-Arifin K, Teasdale R, Ravasi T, Hume DA, Mattick JS, RIKEN GER Group, GSL Members: Identification and analysis of chromodomain-containing proteins encoded in the mouse transcriptome. Genome Res 2003, 13:1416-1429.

5. Marfella CGA, Imbalzano AN: The Chd family of chromatin remodelers. Mutat Res 2007, 618:30-40.

6. Neale BM, Kou Y, Liu L, Ma'ayan A, Samocha KE, Sabo A, Lin CF, Stevens C, Wang LS, Makarov V, Polak P, Yoon S, Maguire J, Crawford EL, Campbell NG, Geller ET, Valladares O, Schafer C, Liu H, Zhao T, Cai G, Lihm J, Dannenfelser R, Jabado O, Peralta Z, Nagaswamy U, Muzny D, Reid JG, Newsham I, Wu Y, et al: Patterns and rates of exonic de novo mutations in autism spectrum disorders. Nature 2012, 485:242-245.

7. O'Roak BJ, Vives L, Fu W, Egertson JD, Stanaway IB, Phelps IG, Carvill G, Kumar A, Lee C, Ankenman K, Munson J, Hiatt JB, Turner EH, Levy R, O'Day DR, Krumm N, Coe BP, Martin BK, Borenstein E, Nickerson DA, Mefford HC, Doherty D, Akey JM, Bernier R, Eichler EE, Shendure J: Multiplex targeted sequencing identifies recurrently mutated genes in autism spectrum disorders. Science 2012, 338:1619-1622.

8. O'Roak BJ, Vives L, Girirajan S, Karakoc E, Krumm N, Coe BP, Levy R, Ko A, Lee C, Smith JD, Turner EH, Stanaway IB, Vernot B, Malig M, Baker C, Reilly B, Akey JM, Borenstein E, Rieder MJ, Nickerson DA, Bernier R, Shendure J, Eichler EE: Sporadic autism exomes reveal a highly interconnected protein network of de novo mutations. Nature 2012, 485:246-250.

9. Capelli LP, Krepischi ACV, Gurgel-Giannetti J, Mendes MF, Rodrigues T, Varela MC, Koiffmann CP, Rosenberg C: Deletion of the RMGA and CHD2 genes in a child with epilepsy and mental deficiency. Eur J Med Genet 2012, 55:132-134

10. Pinto D, Pagnamenta AT, Klei L, Anney R, Merico D, Regan R, Conroy J, Magalhaes TR, Correia C, Abrahams BS, Almeida J, Bacchelli E, Bader GD, Bailey AJ, Baird G, Battaglia A, Berney T, Bolshakova N, Bölte S, Bolton PF, Bourgeron T, Brennan S, Brian J, Bryson SE, Carson AR, Casallo G, Casey J, Chung $\mathrm{BH}$, Cochrane L, Corsello C, et al: Functional impact of global rare copy number variation in autism spectrum disorders. Nature 2010, 466:368-372.

11. Carvill GL, Heavin SB, Yendle SC, McMahon JM, O'Roak BJ, Cook J, Khan A, Dorschner MO, Weaver M, Calvert S, Malone S, Wallace G, Stanley T, Bye AM, Bleasel A, Howell KB, Kivity S, Mackay MT, Rodriguez-Casero V, Webster R, Korczyn A, Afawi Z, Zelnick N, Lerman-Sagie T, Lev D, Møller RS, Gill D, Andrade DM, Freeman $J$, Sadleir LG, et al: Targeted resequencing in epileptic encephalopathies identifies de novo mutations in CHD2 and SYNGAP1. Nat Genet 2013, 45:825-830.

12. Rauch A, Wieczorek D, Graf E, Wieland T, Endele S, Schwarzmayr T, Albrecht B, Bartholdi D, Beygo J, Di Donato N, Dufke A, Cremer K, Hempel M, Horn D, Hoyer J, Joset P, Röpke A, Moog U, Riess A, Thiel $C T$, Tzschach A, Wiesener A, Wohlleber E, Zweier C, Ekici AB, Zink AM, Rump A, Meisinger C, Grallert H, Sticht $H$, et al: Range of genetic mutations associated with severe nonsyndromic sporadic intellectual disability: an exome sequencing study. Lancet 2012, 380:1674-1682.

13. Epi4K Consortium and Epilepsy Phenome/Genome Project, Allen AS, Berkovic SF, Cossette P, Delanty N, Dlugos D, Eichler EE, Epstein MP, Glauser $\mathrm{T}$, Goldstein DB, Han Y, Heinzen EL, Hitomi Y, Howell KB, Johnson MR, Kuzniecky R, Lowenstein DH, Lu YF, Madou MR, Marson AG, Mefford HC, Esmaeeli Nieh S, O'Brien TJ, Ottman R, Petrovski S, Poduri A, Ruzzo EK, Scheffer IE, Sherr EH, Yuskaitis CJ, Abou-Khalil B, et al: De novo mutations in epileptic encephalopathies. Nature 2013, 501:217-221.

14. Krawczak M, Nikolaus S, von Eberstein H, Croucher PJ, El Mokhtari NE, Schreiber S: PopGen: population-based recruitment of patients and controls for the analysis of complex genotype-phenotype relationships. Community Genet 2006, 9:55-61.

15. Stewart AFR, Dandona S, Chen L, Assogba O, Belanger M, Ewart G, LaRose R, Doelle H, Williams K, Wells GA, McPherson R, Roberts R: Kinesin family member 6 variant Trp719Arg does not associate with angiographically defined coronary artery disease in the Ottawa Heart Genomics Study. J Am Coll Cardiol 2009, 53:1471-1472.

16. The International HapMap 3 Consortium, Altshuler DM, Gibbs RA, Peltonen L, Altshuler DM, Gibbs RA, Peltonen L, Dermitzakis E, Schaffner SF, Yu F, Peltonen L, Dermitzakis E, Bonnen PE, Altshuler DM, Gibbs RA, de Bakker PIW, Deloukas P, Gabriel SB, Gwilliam R, Hunt S, Inouye M, Jia X, Palotie A, Parkin M, Whittaker P, Yu F, Chang K, Hawes A, Lewis LR, Ren Y, Wheeler D, et al: Integrating common and rare genetic variation in diverse human populations. Nature 2010, 467:52.

17. The Wellcome Trust Case Control Consortium, Craddock N, Hurles ME, Cardin N, Pearson RD, Plagnol V, Robson S, Vukcevic D, Barnes C, Conrad 
DF, Giannoulatou E, Holmes C, Marchini JL, Stirrups K, Tobin MD, Wain LV, Yau C, Aerts J, Ahmad T, Andrews TD, Arbury H, Attwood A, Auton A, Ball SG, Balmforth AJ, Barrett JC, Barroso I, Barton A, Bennett AJ, Bhaskar S, Blaszczyk K, et al: Genome-wide association study of CNVs in 16,000 cases of eight common diseases and 3,000 shared controls. Nature 2010, 464:713-720.

18. Itsara A, Cooper GM, Baker C, Girirajan S, Li J, Absher D, Krauss RM, Myers RM, Ridker PM, Chasman DI, Mefford H, Ying P, Nickerson DA, Eichler EE: Population analysis of large copy number variants and hotspots of human genetic disease. Am J Hum Genet 2009, 84:148-161.

19. Silversides CK, Lionel AC, Costain G, Merico D, Migita O, Liu B, Yuen T, Rickaby J, Thiruvahindrapuram B, Marshall CR, Scherer SW, Bassett AS: Rare copy number variations in adults with tetralogy of Fallot implicate novel risk gene pathways. PLoS Genet 2012, 8:e1002843.

20. Bierut L, Agrawal A, Bucholz KK, Doheny KF, Laurie C, Pugh E, Fisher S, Fox L, Howells W, Bertelsen S, Hinrichs AL, Almasy L, Breslau N, Culverhouse RC, Dick DM, Edenberg HJ, Foroud T, Grucza RA, Hatsukami D, Hesselbrock V, Johnson EO, Kramer J, Krueger RF, Kuperman S, Lynskey M, Mann K, Neuman RJ, Nöthen MM, Nurnberger JI Jr, Porjesz B, the Gene, Environment Association Studies (GENEVA) Consortium, et al: A genome-wide association study of alcohol dependence. Proc Natl Acad Sci U S A 2010, 107:5082-5087.

21. Verhoeven VJ, Hysi PG, Wojciechowski R, Fan Q, Guggenheim JA, Höhn R, MacGregor S, Hewitt AW, Nag A, Cheng CY, Yonova-Doing E, Zhou X, Ikram MK, Buitendijk GH, McMahon G, Kemp JP, Pourcain BS, Simpson CL, Mäkelä KM, Lehtimäki T, Kähönen M, Paterson AD, Hosseini SM, Wong HS, Xu L, Jonas JB, Pärssinen O, Wedenoja J, Yip SP, Ho DW, Consortium for Refractive Error and Myopia (CREAM), Diabetes Control and Complications Trial/Epidemiology of Diabetes Interventions and Complications (DCCT/ EDIC) Research Group, Wellcome Trust Case Control Consortium 2 (WTCCC2), Fuchs' Genetics Multi-Center Study Group, et al: Genome-wide meta-analyses of multiancestry cohorts identify multiple new susceptibility loci for refractive error and myopia. Nat Genet 2013, 45:314-318.

22. Coviello AD, Haring $R$, Wellons $M$, Vaidya $D$, Lehtimäki $T$, Keildson $S$, Lunetta $\mathrm{KL}$, He C, Fornage M, Lagou V, Mangino M, Onland-Moret NC, Chen B, Eriksson J, Garcia M, Liu YM, Koster A, Lohman K, Lyytikäinen LP, Petersen AK, Prescott J, Stolk L, Vandenput L, Wood AR, Zhuang W, Ruokonen A, Hartikainen AL, Pouta A, Bandinelli S, Biffar R, et al: A genome-wide association meta-analysis of circulating sex hormone-binding globulin reveals multiple loci implicated in sex steroid hormone regulation. PLoS Genet 2012, 8:e1002805.

23. Costain G, Lionel AC, Merico D, Forsythe P, Russell K, Lowther C, Yuen T, Husted J, Stavropoulos DJ, Speevak M, Chow EW, Marshall CR, Scherer SW, Bassett AS: Pathogenic rare copy number variants in community-based schizophrenia suggest a potential role for clinical microarrays. Hum $\mathrm{Mol}$ Genet 2013, 22:4485-4501.

24. Qi L, Cornelis MC, Kraft P, Stanya KJ, Kao WHK, Pankow JS, Dupuis J, Florez JC, Fox CS, Paré G, Sun Q, Girman CJ, Laurie CC, Mirel DB, Manolio TA, Chasman DI, Boerwinkle E, Ridker PM, Hunter DJ, Meigs $\mathrm{JB}$, Lee $\mathrm{CH}$, Hu FB, van Dam RM, Meta-Analysis of Glucose and Insulinrelated traits Consortium (MAGIC); Diabetes Genetics Replication and Meta-analysis (DIAGRAM) Consortium: Genetic variants at 2q24 are associated with susceptibility to type 2 diabetes. Hum Mol Genet 2010, 19:2706-2715.

25. Below JE, Gamazon ER, Morrison JV, Konkashbaev A, Pluzhnikov A, McKeigue PM, Parra EJ, Elbein SC, Hallman DM, Nicolae DL, Bell Gl, Cruz M, Cox NJ, Hanis CL: Genome-wide association and meta-analysis in populations from Starr County, Texas, and Mexico City identify type 2 diabetes susceptibility loci and enrichment for expression quantitative trait loci in top signals. Diabetologia 2011, 54:2047-2055.

26. Zogopoulos G, Ha KC, Naqib F, Moore S, Kim H, Montpetit A, Robidoux F, Laflamme P, Cotterchio M, Greenwood C, Scherer SW, Zanke B, Hudson TJ, Bader GD, Gallinger S: Germ-line DNA copy number variation frequencies in a large North American population. Hum Genet 2007, 122:345-353.

27. Kulkarni S, Nagarajan P, Wall J, Donovan DJ, Donell RL, Ligon AH, Venkatachalam S, Quade BJ: Disruption of chromodomain helicase DNA binding protein 2 (CHD2) causes scoliosis. Am J Med Genet A 2008, 146A:1117-1127.

28. Suls A, Jaehn JA, Kecskés A, Weber Y, Weckhuysen S, Craiu DC, Siekierska A, Djémié T, Afrikanova T, Gormley P, von Spiczak S, Kluger G, Iliescu CM, Talvik
T, Talvik I, Meral C, Caglayan HS, Giraldez BG, Serratosa J, Lemke JR, Hoffman-Zacharska D, Szczepanik E, Barisic N, Komarek V, Hjalgrim H, Møller RS, Linnankivi T, Dimova P, Striano P, Zara F, the EuroEPINOMICS RES Consortium: De novo loss-of-function mutations in CHD2 cause a feversensitive myoclonic epileptic encephalopathy sharing features with Dravet syndrome. Am J Hum Genet 2013, 93:967-975.

doi:10.1186/1866-1955-6-9

Cite this article as: Chénier et al:: CHD2 haploinsufficiency is associated with developmental delay, intellectual disability, epilepsy and neurobehavioural problems. Journal of Neurodevelopmental Disorders 2014 6:9.

\section{Submit your next manuscript to BioMed Central and take full advantage of:}

- Convenient online submission

- Thorough peer review

- No space constraints or color figure charges

- Immediate publication on acceptance

- Inclusion in PubMed, CAS, Scopus and Google Scholar

- Research which is freely available for redistribution

Submit your manuscript at www.biomedcentral.com/submit
C) Biomed Central 